\title{
BACKGRound ConCENTRATIONS OF CHEMicAl ElEMENTS IN SEPETIBA BAY (SE BRAZIL)
}

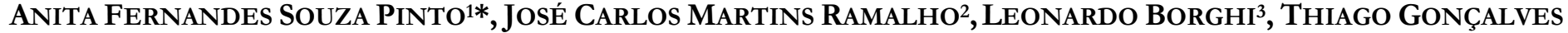 Carelli $^{3}$, Josiane Branco PlantZ ${ }^{3}$, Egberto Pereira ${ }^{1}$, Denise Terroso ${ }^{4}$, Werlem Holanda Dos Santos ${ }^{1}$, MAURo CÉSAR GERALDES ${ }^{1}$, FERNANDo RoCHA ${ }^{4}$, MARIA ANTONIETA DA CONCEIÇÃo RodRIGUES ${ }^{1}$, LAZARo LAUT ${ }^{5}$ AND MARIA ViRgÍNIA ALVES MARTINS1, 4}

1. Universidade do Estado do Rio de Janeiro - UERJ, Faculdade de Geologia, Departamento de Paleontologia e Estratigrafia, Rio de Janeiro, RJ, Brazil

2 Universidade Federal do Espírito Santo, Vitória, Espírito Santo, Brazil

3 Universidade Federal do Rio de Janeiro, Instituto de Geociências, Departamento de Geologia, Rio de Janeiro, RJ, Brazil.

4 Universidade de Aveiro, Departamento de Geociências, GeoBioTec, Aveiro, Portugal

5 Universidade Federal do Estado do Rio de Janeiro - UNIRIO, Laboratório de Micropaleontologia - LABMICRO, Rio de Janeiro, RJ, Brazil

*CORRESPONDING AUTHOR, anitafspinto@gmail.com

Received on on 10 March 2019

Received in revised form on 22 March 2019

Accepted on 24 March2019

Editor: Noureddine Zaaboub, Institut National des Sciences et Technologies de la Mer, Tunisia

\section{Abstract}

This study intends to evaluate baseline concentrations of chemical elements for unpolluted sediments of Sepetiba Bay (SE Brazil). It analyzes the concentrations of potentially toxic elements (PTE) and other chemical elements (by Inductively Coupled Plasma Mass Spectrometry and Inductively Coupled Plasma Emission Spectrometry) from the upper part of the SP2 drillcore (or 2-SPT-1-RJ; with $50.30 \mathrm{~m}$ length), collected on the margins of Sepetiba Bay (at latitude $22^{\circ} 55^{\prime} \mathrm{S}$ and longitude $\left.43^{\circ} 46^{\prime} \mathrm{W}\right)$. This core was described and sampled. Textural, mineralogical and geochemical analyses were performed in 17 sediment levels. The sediment layers of interest were selected, considering the period in which they were deposited, before high anthropic influence in the area, and on sediment grain-size. Only the muddy levels were

\section{Introduction}

The mineralogical composition of soils and surface sediments is a function of source rock, parent material, physical and chemical properties of minerals, sedimentary processes (transport cycles, deposition and remobilization), types and intensity of weathering, grain size and others (Nesbitt and Young, 2008). The sediment compositional characteristics are also related to the local hydrodynamics, biogeochemical processes that occur during the sedimentary cycles and, diverse sources of sedimentary particles, namely organic matter and other biogenic materials, at the sediment

\begin{abstract}
Citation:
Pinto, A.F.S., Ramalho, J.C.M., Borghi, L., Carelli, T.G., Plantz, J.B., Pereira, E., Terroso, D., Santos, W.H., Geraldes, M.C., Rocha, F., Rodrigues, M.A.C., Laut, L., Martins, M.V.A., 2019. Background concentrations of chemical elements in Sepetiba Bay (SE Brazil). Journal of Sedimentary Environments, 4 (1): 108-123.
\end{abstract}

selected, since fine sediments generally tend to have higher elemental concentrations. Foraminiferal occurrence was also analyzed in the selected layers. The results indicate that the studied sediments were deposited in a transitional marine context, after being exposed to multiple sedimentary cycles and weathering. The baseline concentrations, related to natural sediment sources were estimated for As, Cd, Co, Cr, $\mathrm{Cu}, \mathrm{Ni}, \mathrm{Pb}, \mathrm{Zn}$ ) and $\mathrm{P}$ and for other chemical elements. These results are useful in environmental impact assessment not only in the study area, but also for other coastal regions of Rio de Janeiro State.

Keywords: Multiproxy approach. Sediments. Holocene Records. Coast. South Atlantic.

deposition site (Holland and Turekian, 2014).

However, trace element concentrations of soils and sediments deposited in different contexts have been increasing considerably with the intensification of urban, agricultural and industrial activities (Wolanski and McLusky, 2011). Human interference in natural ecosystems has been increasing the concentrations of trace elements in soils and sediments in various environments (Tack et al., 1997; Marchand et al. 2016). The expansion of economic and industrial activities along the coastal areas have 
unquestionably introduced metals into marine sediments (Muniz et al., 2004; Wolanski and McLusky, 2011). Such input of metals represents a serious socio-environmental problem, since coastal regions constitute an important source of food and other resources for the populations that inhabit them (Araújo et al., 2017). Potentially dangerous trace elements are brought to the marine environment by the direct discharge of urban waste and industrial effluents and can be transported through the atmosphere from their source to coastal locations (Cardoso et al., 2001; Kasilingam et al., 2016).

Due to these influences, it is difficult to estimate the true geochemical background levels of trace elements in soils and marine sediments (Dung et al., 2013). Geochemical background concentrations should represent natural concentrations, which ideally exclude human influence (Tack et al., 1997). Geochemical baselines, in contrast, represent a concentration to one specific area and time and are not always true backgrounds (Tack et al., 1997). Therefore, several studies proposing determination methods have been performed (e.g. Tack et al., 1997; Matschullat et al., 2000; Reimann and Garrett, 2005; Gałuszka and Migaszewski, 2011; Desaules, 2012).

The geochemical backgrounds from marine sediments, provide an approach on the present environmental quality of the ecosystem, but also serve as a baseline for future investigations (Kasilingam et al., 2016). Due to the growing urbanization rate and fast and unplanned development, many tropical coastal areas in Brazil are being affected by accelerated processes of ecosystems degradation (Gomes et al., 2009; Araújo et al., 2017). In southeastern Brazil, the
Sepetiba Bay is suffering environmental disturbances due to anthropic activities (e.g. Pellegati et al., 2001; Wasserman et al., 2001; Marques et al., 2006; Gomes et al., 2009; Herms and Gurgel, 2012) mainly since the 1950s - intense urbanization, increased industrial activity and diversion of waters from the main river that drains the region, Guandu River, in order to respond to grow demands (Rodrigues et al, 2012). However, the baseline concentration levels of trace elements for Sepetiba Bay (SE Brazil) were not yet determined. Therefore, this work intends to evaluate the baseline concentration levels of PTE and other lithogenic elements of unpolluted sediments of Sepetiba Bay, considering sedimentary records prior to the Historical period and the higher anthropic influence in this region (Lacerda et al., 1987).

\subsection{Study Area}

Sepetiba Bay, situated between the latitudes $22^{\circ} 55^{\prime} \mathrm{S}-23^{\circ}$ $05^{\prime} \mathrm{S}$ and longitudes $43^{\circ} 35^{\prime} \mathrm{W}-44^{\circ} 00^{\prime} \mathrm{W}$ is one of the three large bays of Rio de Janeiro State, with the others being Guanabara and Ilha Grande bays. It has an ellipsoidal shape, $40-\mathrm{km}$ long and $6-\mathrm{km}$ wide, total area of $\approx 519 \mathrm{~km}^{2}$ and volume of $\approx 2.56 \times 10^{9} \mathrm{~m}^{3}$ (Molisani et al., 2004; Villena et al., 2012; Fig. 1).

With characteristics of a semi-confined lagoon, Sepetiba Bay is bounded at north by the continent, at east by Guaratiba tidal plain, at south by Marambaia Sand Ridge as well as a string of migmatitic islands (Suguio et al., 1979; Brönnimann et al., 1981; Roncarati and Carelli, 2012; Villena et al., 2012; Araújo et al., 2017).

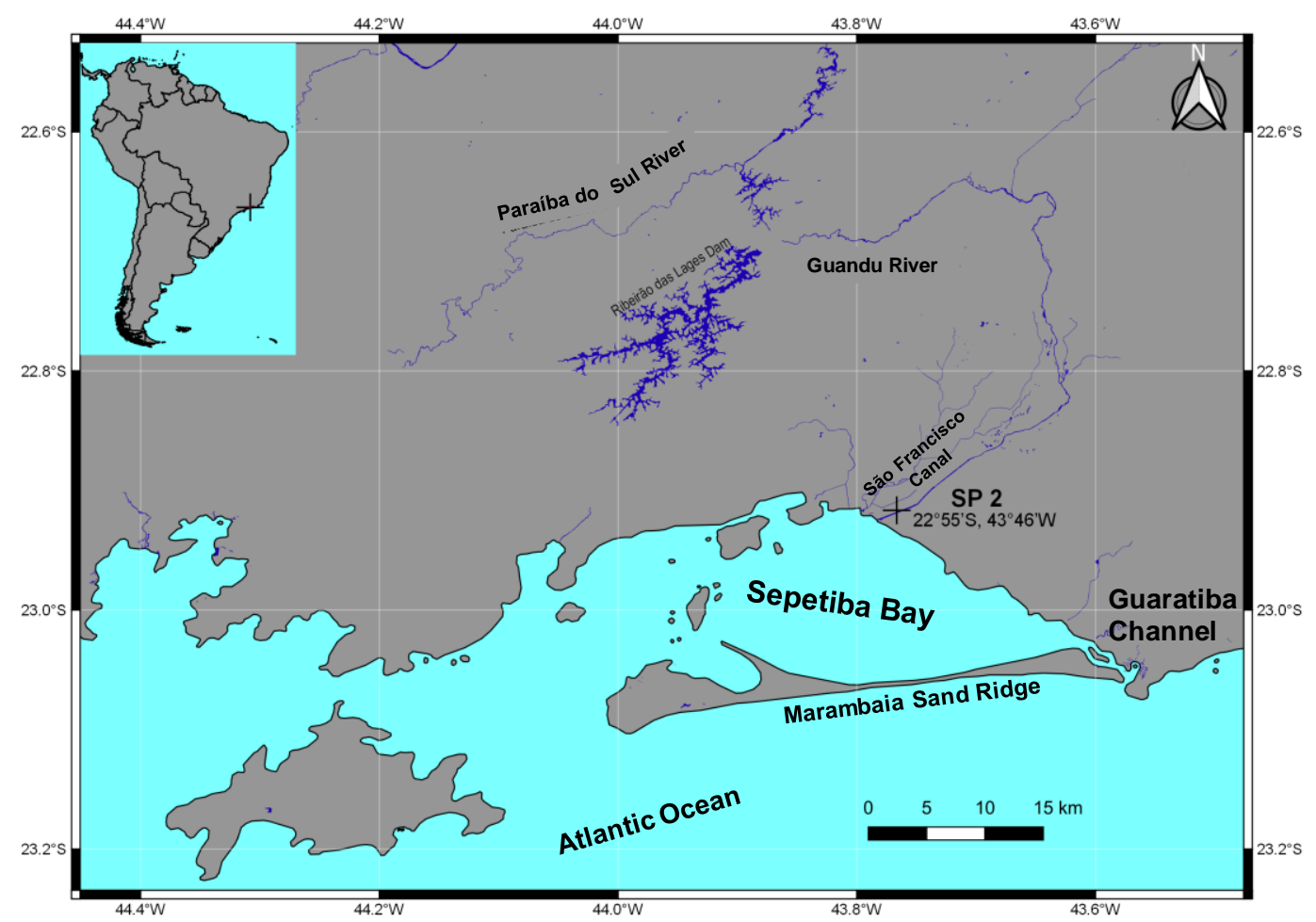

Fig. 1. Localization map showing the Sepetiba Bay, located at the southern region of Rio de Janeiro State. Note the position of analyzed drillcore. 
The communication between Sepetiba Bay and the ocean occurs at the western mouth, between the mainland and the Marambaia Sand Ridge, and to the east, to a lesser extent, through the Guaratiba Channel. According to Ponçano et al. (1979) the mouths of the rivers that flow into Sepetiba Bay are concentrated in its northern margin, with emphasis on the Guandu River.

From the geological point of view, the study area is related to the Mantiqueira Province (Almeida and Carneiro, 1998), a geotectonic entity that encompasses the Ribeira Belt (Heilbron et al., 2004 a,b; Silva et al., 2005; Trouw et al., 2013). According to Heilbron et al. (2004b), the Ribeira Belt is composed by remobilized and metamorphosed Proterozoic rocks in the Brazilian Cycle (720-590 Ma), which eventually formed complex geological units, individualized by ENEWSW tectonic discontinuities. The adjacent regions present several different lithographic units, such as Neoproterozoic rocks with clear NE-SW strike, Cenozoic alkaline rocks intrusions and fluvial-marine quaternary sediments scattered in the lowland (SEMA-ZEE/RJ, 1996; Fig.2).

Among the Neoproterozoic units are ortho-derivative rocks (tonalites, granodiorites, granites and foliated gabbro) of the Rio Negro Complex, plutonic portion of a magmatic arc of 790-600 Ma (Tupinambá et al., 2000; Heilbron and Machado, 2003), as well as ortho-derivative rocks associated with the Rio Turvo granitoid, of 579 \pm 6 Ma (Machado et al., 1996; Valeriano et al., 2012). The reactivation in the Mesozoic of the Pre-Cambrian weakness zones provided the relief framework, which houses the NE-oriented coastal plains and the Serra do Mar main escarpment, as well as islets and isolated hills and the Cenozoic sediments (Roncarati and Carelli, 2012).

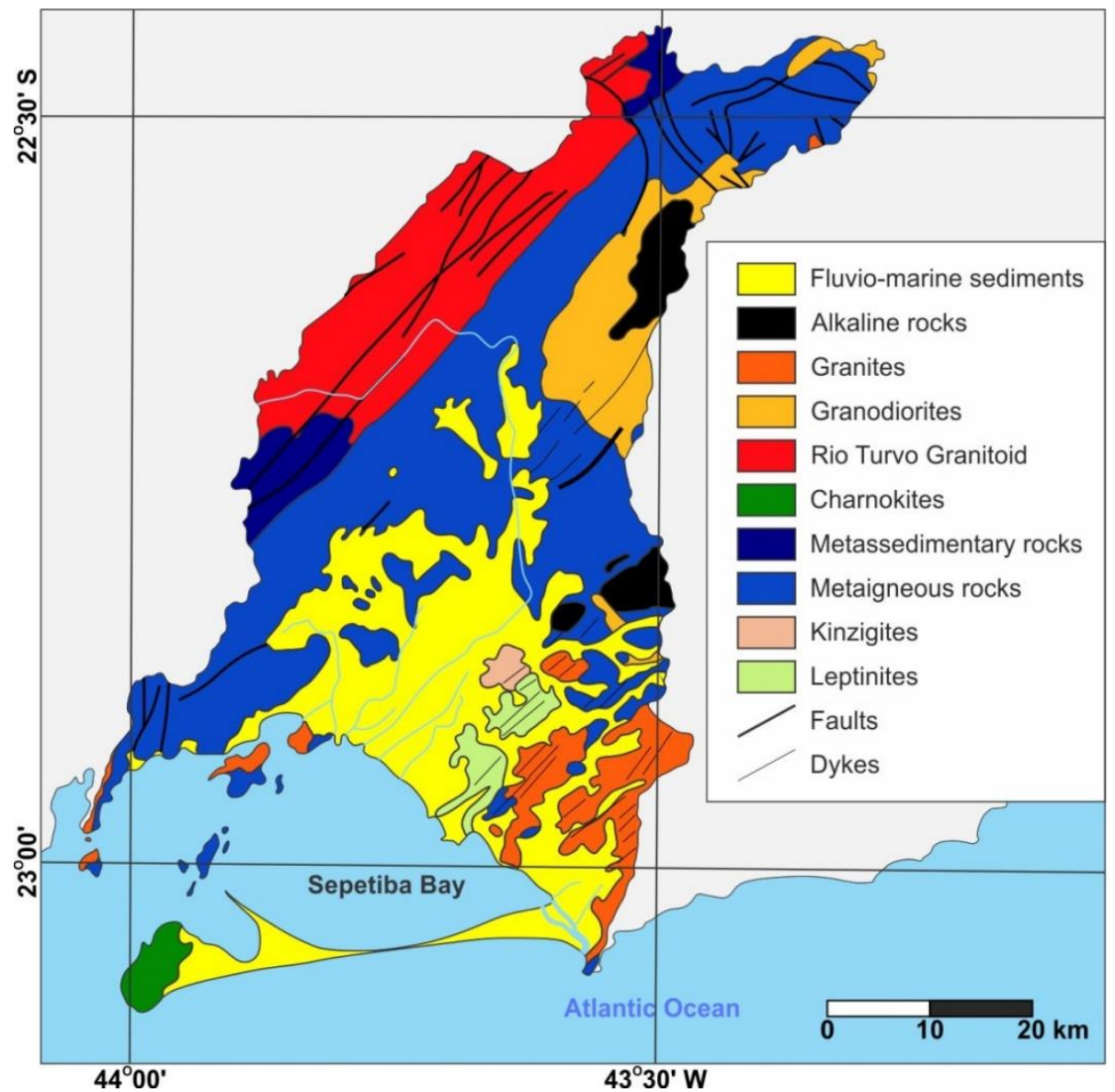

Fig. 2. Geological regional map displaying the main geological features that occur in the area of the Sepetiba Bay hydrographic basin (modified from SEMA ZEE/RJ, 1996).

Alkaline intrusive rock bodies are also observed, mainly of dike form. The dikes have preferential NE orientation, and subordinately, NW orientation. The intrusions are represented by the Tinguá and Mendanha massifs, forming high altitudes in these regions, since these lithological types are resistant to erosion due to their mineralogical composition and structural conformity (Ponçano et al., 1979; SEMADS, 2001).
The quaternary sediments of the coastal plains comprise fluvial sediments, tidal channels and mangrove sediments where fine clastic sediments, clayey silt and silty sand predominate. However, in stretches such as the regions along Guaratiba Sand Ridge, in the areas adjacent to the sea and near the mouth of the São Francisco Canal - where a small delta and river processes occur - the sediments are thicker and sandy (SEMADS, 2001). 
According to Suguio et al. (1979), the sedimentary coverture of Sepetiba Bay comes from external and internal sources. From an external source, they reach the bay through the river drainage network that flows into the northern part of the water body, especially the Guandu River. The internal source of the sediments is represented by sands resulting from the erosion of Guaratiba Sand Ridge (Brönnimann et al., 1981).

The sediments that arrive to the Sepetiba lowland are brought essentially by the rivers that drain this region and by the rivers coming from the Serra do Mar. The course of these rivers is heavily controlled by basement structural directions, and they eventually carry sediments from higher lands (CPRM, 2001).

The coastal plains that are found in the almost flat lowlands, skirting elevations formed by Neoproterozoic rocks and forming the Sepetiba lowland and the Marambaia Sand Ridge, show a variety of depositional environments constructed during the Quaternary (Roncarati and Barrocas, 1978; Roncarati and Carelli, 2012; Borges and Nittrouer, 2016 $\mathrm{a}, \mathrm{b})$. These sediments underwent intense reworking during climatic oscillations and sea level changes, which affected the Rio de Janeiro coast during the Plio-Pleistocene (Maia et al., 2010).

Along the coastline, associated with the lowland, extensive swampy areas are identified. The formation of these areas is related to the geomorphological configuration of the region, characterized by a horizontal profile at sea level. Due to this effect, the rivers reach the base level hundreds of meters, or even kilometers, before launching into the sea, giving rise to flooded areas, such as mangroves and marshes surrounding Sepetiba Bay. These swampy coastal plains have been submitted to drainage works, with the rectification of rivers, such as the São Francisco Canal, and the construction of other canals (CPRM, 2001).

\section{Materials and Methods}

The present work analyzes the textural, mineralogical and geochemical composition of the upper part of the SP2 sediment core (initial reference 2-SPT-1-RJ; with $50.30 \mathrm{~m}$ length). Foraminifera density also was analyzed.

The SP2 core was obtained by rotary drilling through a Mach 1200 model drilling rig in October 2013 at the northern margins of Sepetiba Bay (at latitude $22^{\circ} 55^{\prime} \mathrm{S}$ and longitude $43^{\circ}$ 46'W; Fig. 1), in collaboration with the Sedimentary Geology Laboratory of the Universidade Federal do Rio de Janeiro (Lagesed - UFRJ). The survey area is located in the vicinity of Santa Cruz Thermoelectric Power Plant, in the Industrial District of Santa Cruz, at west of the municipality of Rio de Janeiro (SE Brazil). Figure 3 (A, B) shows the structure of the Mach 1200 rotary probe used to collect the SP2 drillcore. The sediments were collected in successive sessions of $1.50 \mathrm{~m}$. Each session was stored in identified wooden boxes, with the core and section depth identification and the respective top and base indication.

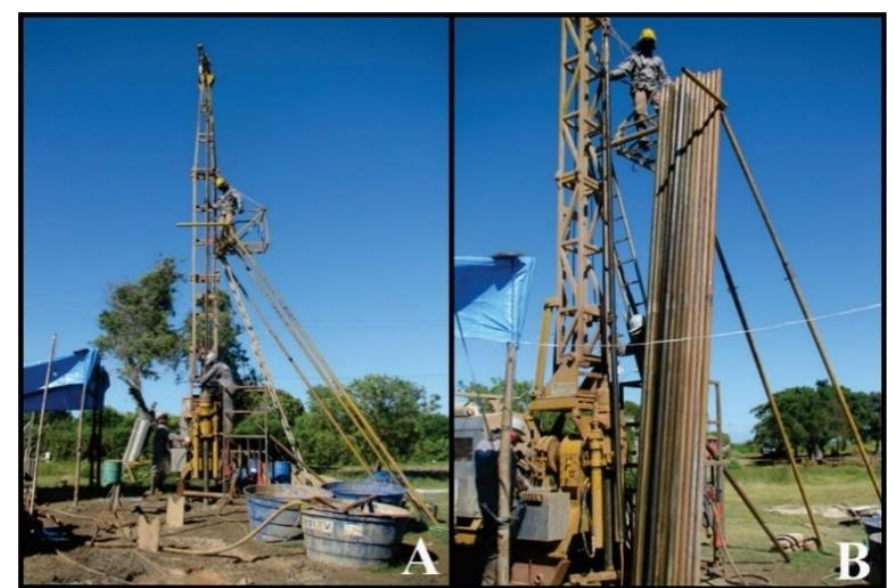

Fig. 3. A, B. shows the Mach 1200 drilling rig during SP2 core acquisition.

The SP2 drillcore was described in detail (1:40 scale), based on lithology, sedimentary structures, colors, fossils and bedding surfaces (Selley, 1970). Its description was facilitated by the use of a stereomicroscope (Zeiss Stemi 2000-C).

Basement rock was found in SP2 core between $50.30 \mathrm{~m}$ and $43.80 \mathrm{~m}$ depth. The first $\approx 2.00 \mathrm{~m}$ of this core consist of embankment sediments, so they were not considered in this study. The sedimentary package, deposited on the basement that extends from $43.80 \mathrm{~m}$ to $21.15 \mathrm{~m}$, is composed of very coarse to medium sands, corresponding to sediments deposited in continental sub-air environment, as revealed by the textural and compositional analyses of the sediments (see the results section for more detailed description). For this reason, this section (43.80-21.15 m) was not also considered in this study. The sedimentary package between $20.95-2.00 \mathrm{~m}$ was selected, due to its predominance of fine-grained sediments, foraminifera tests in almost all its extension. In this core section, 17 fine-grained sediment layers, were selected for textural, mineralogical and geochemical analyses, collected at each $5 \mathrm{~cm}$ ( $5 \mathrm{~cm}$ thick samples).

About $30 \mathrm{~g}$ of sediment were reserved for granulometric analysis, $250 \mathrm{mg}$ for Total Organic Carbon (TOC) and Total Sulfur (S). For the geochemical and mineralogical analyzes, approximately $3 \mathrm{~g}$ and $11 \mathrm{~g}$ of fine sediment fraction $(<63 \mu \mathrm{m})$ were separated, respectively.

\subsection{Particle size analysis}

The particle size analysis was performed on the selected section (20.95-2.00 m), by sieving. For textural analysis, firstly the whole sediment samples were dried, to determine their initial weight. Then, they were washed with distilled water in a $63 \mu \mathrm{m}$ sieve to separate the sandy $(>63 \mu \mathrm{m})$ from the fine $(<63 \mu \mathrm{m})$ sediments. The separated sand and fine fractions were oven-dried at about $50{ }^{\circ} \mathrm{C}$ in beakers. After drying, both fractions were weighed and stored in identified plastic bags. The sandy fraction was submitted to granulometric analysis, by dry sieving in a series of sieves with the following meshes: $2000 \mu \mathrm{m}, 1000 \mu \mathrm{m}, 500 \mu \mathrm{m}, 250 \mu \mathrm{m}$ and $125 \mu \mathrm{m}$. 
The weight retained in each of these sieves was registered. The percentage of gravel, very coarse sand, coarse sand, medium sand, fine sand and very fine sand fractions was determined. The fine fraction was classified generically as fine sediments. Like Blott and Pye (2001), the granulometric data were statistically treated in Gradistat, an Excel-based program which calculates the statistical parameters according to Folk and Ward (1957).

\subsection{Mineralogical analysis}

Mineralogical analysis was carried out in the sediments fine fraction $(<63 \mu \mathrm{m})$. After drying in an oven at $50{ }^{\circ} \mathrm{C}$, these materials were analyzed for mineralogical analysis by X-Ray Diffraction (XRD). This technique aims to identify and semiquantify the mineralogical component $(<63 \mu \mathrm{m})$ in nonoriented aggregates, such as quartz, feldspars, calcite, phyllosilicates, sulfides, anhydrite, among others, and clay minerals $(<2 \mu \mathrm{m})$ in oriented aggregates, such as kaolinite, illite, smectite and chlorite (Schultz, 1964; Thorez, 1976). The samples preparation and the semi-quantification followed the methodology described by Martins et al. (2007).

\subsection{Total Organic Carbon (TOC) and Total Sulfur (S)}

The determination of TOC and S percentages was carried out, based on the methodology of Espitalié et al. (1977). Firstly, the samples were desegregated and sieved in an 80mesh sieve. The finer fraction was analyzed for TOC and S. Then, an acid attack was performed with $50 \% \mathrm{HCl}$ for approximately 12 hours, in order to eliminate the carbonates. After acidification, the samples were washed five times. The first wash was done with distilled water at $100{ }^{\circ} \mathrm{C}$ and the other washes at room temperature, to eliminate the chlorides formed by $\mathrm{HCl}$. Finally, the samples were dried in a light bath at $80^{\circ} \mathrm{C}$ and weighed again.

The samples, already free of carbonates, were submitted to a temperature of $1,350{ }^{\circ} \mathrm{C}$ until their complete combustion in the LECO SC-634 analyzer. During combustion, the resulting $\mathrm{CO}_{2}$ was charged to the infrared cell and detected, as well as sulfur in the form of $\mathrm{SO}_{2}$. With the calibration based on standard samples introduced before and after the analyzes, the amounts of $\mathrm{CO}_{2}$ and $\mathrm{SO}_{2}$ detected directly gave percentages by weight of TOC and S, depending on the initial weight of the sample before acidification.

\subsection{Elementary geochemical analysis}

The elemental geochemical analyzes were performed at the ACME Laboratory (Analytical Laboratories LTD), Vancouver, Canada. The elemental concentrations were determined by total acid digestion (with 4 acids, $\mathrm{HNO}_{3}$ $\mathrm{HClO}_{4}-\mathrm{HF}$ and $\mathrm{HCl}$ ) and the quantification of concentrations in spectrometry, in two combined forms: Inductively Coupled Plasma Mass Spectrometry (ICP-MS) and Inductively Coupled Plasma Emission Spectrometry (ICP-ES).
Concentrations of Ag, Al, As, Be, Bi, Ca, Cd, Co, Cr, Cu, Fe, K, La, Mg, Mn, Mo, Na, Nb, Ni, P, Pb, Sc, Sn, Sr, Th, Ti, V, $\mathrm{Y}, \mathrm{Zn}$ and $\mathrm{Zr}$ were estimated in selected fine-grained sediment layers from the upper part of the SP2 core, at depths between $3.6 \mathrm{~m}$ and $16.85 \mathrm{~m}$. The lower detected concentrations of the analyzed elements by ICP ES/MS are shown in Table 1.

\subsection{Foraminifera density}

In this study, the foraminifera density was determined in a constant volume of sediment $(10 \mathrm{ml})$ collected from the selected layers. The initial total sediment was washed with distilled water in a $63-\mu \mathrm{m}$ sieve mesh. In each sample, the foraminifera density - number of specimens per gram of 63$500 \mu \mathrm{m}$ fraction was determined, with a light Zeiss Stemi 2000-C.

\subsection{Radiocarbon dating}

Mollusk shells, recovered at two levels of SP2 core $(6.20$ $\mathrm{m}$ and $17.60 \mathrm{~m})$, were sent for radiocarbon dating $\left({ }^{14} \mathrm{C}\right)$ at the Beta Analytic Inc. Laboratory (Florida, USA). The method, which uses Mass Spectrometry with Accelerators (AMS), provides conventional ages in years before the present (BP) which were calibrated in years before present (yrs cal. BP; Talma and Vogel, 1993; Reimer et al., 2013).

\subsection{Statistical Analyses and location map}

Geochemical data were normalized by $\log (\mathrm{x}+1)$ and used for the determination of Pearson correlations and were submitted to Principal Components Analysis (PCA). These statistical analyses were performed using a Statsoft software (Statistica 12). The location map was performed with the qGIS version "Madeira".

\section{Results}

\subsection{Radiocarbon Dating}

Table 2 presents the results of radiocarbon dating at two levels of SP2 core: $6.20 \mathrm{~m}$ and $17.60 \mathrm{~m}$. The obtained radiocarbon data allow to estimate the ages 1,890 $\pm 110 \mathrm{yrs}$ cal. BP and 4,602 $\pm 178 \mathrm{yrs}$ cal. BP for the levels $6.20 \mathrm{~m}$ to $17.60 \mathrm{~m}$, respectively.

\subsection{General description of the core}

The stratigraphic profile and granulometric log of 2-SPT1-RJ drillcore, where three distinct lithological intervals (A, B and $\mathrm{C}$ ) were identified is presented in Fig. 4.

Interval A - This interval occurs between 2.00 to 21.15 meters depth. It is characterized by an expressive muddy section that exhibit dark gray color as well as whole or fragmented mollusk shells and plant debris. Layers of angular, poorly sorted, fine to medium sands containing quartz and 
feldspar granules and, at times, clay intraclasts occurs interbedded. Quartz, feldspar, muscovite and biotite are the most abundant minerals.

Interval B - This interval occurs between 21.15 to 44.00 meters depth. It is characterized by angular, poorly to moderate sorted, immature, very coarse to medium sands displaying grayish or, more rarely, yellowish colors, organized in metric scale depositional cycles that exhibit a week finning upward trend. These layers are composed essentially by quartz, feldspar, biotite and rare muscovite. Granules are abundant and occur disperse or concentrated at the base of some layers.

Interval C - This interval occurs between 44.00 to 50.30 meters depth. It is characterized by the light gray, fine to medium grained, melanocratic biotite gneiss that exhibit a equigranular texture (subhedral grains), often cut by quartz and quartz/feldspar layers.

Tab. 1. The lower detected concentrations of the elements extracted by acid digestion and quantification by ICP ES/MS.

\begin{tabular}{|c|c|c|c|}
\hline Element & Detected Concentration & Element & Detected Concentration \\
\hline$A g$ & $0.01 \%$ & $N i$ & $0.001 \%$ \\
\hline$A l$ & $1 \mathrm{mg} / \mathrm{kg}$ & $P$ & $0.1 \mathrm{mg} / \mathrm{kg}$ \\
\hline As & $1 \mathrm{mg} / \mathrm{kg}$ & $\mathrm{Pb}$ & $0.1 \mathrm{mg} / \mathrm{kg}$ \\
\hline$B e$ & $0.1 \mathrm{mg} / \mathrm{kg}$ & $R b$ & $0.005 \mathrm{mg} / \mathrm{kg}$ \\
\hline$B i$ & $0.01 \%$ & $\mathrm{Re}$ & $0.1 \%$ \\
\hline $\mathrm{Ca}$ & $0.1 \mathrm{mg} / \mathrm{kg}$ & $S b$ & $1 \mathrm{mg} / \mathrm{kg}$ \\
\hline$C d$ & $1 \mathrm{mg} / \mathrm{kg}$ & Sc & $1 \mathrm{mg} / \mathrm{kg}$ \\
\hline$C e$ & $0.2 \mathrm{mg} / \mathrm{kg}$ & Se & $0.1 \mathrm{mg} / \mathrm{kg}$ \\
\hline Co & $1 \mathrm{mg} / \mathrm{kg}$ & $S n$ & $1 \mathrm{mg} / \mathrm{kg}$ \\
\hline $\mathrm{Cr}$ & $0.1 \mathrm{mg} / \mathrm{kg}$ & Sr & $0.1 \mathrm{mg} / \mathrm{kg}$ \\
\hline$C u$ & $0.01 \%$ & $\mathrm{Ta}$ & $0.5 \mathrm{mg} / \mathrm{kg}$ \\
\hline $\mathrm{Fe}$ & $0.1 \mathrm{mg} / \mathrm{kg}$ & $\mathrm{Te}$ & $0.1 \mathrm{mg} / \mathrm{kg}$ \\
\hline$H f$ & $0.05 \mathrm{mg} / \mathrm{kg}$ & $T h$ & $0.001 \%$ \\
\hline In & $0.01 \%$ & $\mathrm{Ti}$ & $0.5 \mathrm{mg} / \mathrm{kg}$ \\
\hline K & $0.1 \mathrm{mg} / \mathrm{kg}$ & $\mathrm{Tl}$ & $0.1 \mathrm{mg} / \mathrm{kg}$ \\
\hline$L a$ & $0.1 \mathrm{mg} / \mathrm{kg}$ & $U$ & $4 \mathrm{mg} / \mathrm{kg}$ \\
\hline$L i$ & $0.01 \%$ & V & $0.1 \mathrm{mg} / \mathrm{kg}$ \\
\hline$M g$ & $1 \mathrm{mg} / \mathrm{kg}$ & $W$ & $0.1 \mathrm{mg} / \mathrm{kg}$ \\
\hline$M n$ & $0.1 \mathrm{mg} / \mathrm{kg}$ & $Y$ & $1 \mathrm{mg} / \mathrm{kg}$ \\
\hline Mo & $0.001 \%$ & $Z n$ & $0.1 \mathrm{mg} / \mathrm{kg}$ \\
\hline $\mathrm{Na}$ & $0.1 \mathrm{mg} / \mathrm{kg}$ & $\mathrm{Zr}$ & $0.1 \mathrm{mg} / \mathrm{kg}$ \\
\hline $\mathrm{Nb}$ & $0.1 \mathrm{mg} / \mathrm{kg}$ & & \\
\hline
\end{tabular}

Tab. 2. Measured, conventional, and calculated radiocarbon ages before present (BP) are presented for two levels of SP2 core. Legend. Cal - calibrate; BP - before present.

\begin{tabular}{cccc}
\hline $\begin{array}{c}\text { Depth } \\
(\mathrm{m})\end{array}$ & $\begin{array}{c}\text { Measured age } \\
\text { (years BP) }\end{array}$ & $\begin{array}{c}\text { Calibrated conventional age } \\
\text { (years BP) }\end{array}$ & $\begin{array}{c}\text { Calibrated age } \\
\text { (years cal. BP) }\end{array}$ \\
\hline $\mathbf{6 . 2 0}$ & $1.830 \pm 30$ & $2.220 \pm 30$ & 2.000 to 1.780 \\
& & $4.890 \pm 110)$ \\
\hline $\mathbf{1 7 . 6 0}$ & $3.940 \pm 30$ & $460 \pm 30$ & 4.780 to 4.425 \\
& & & $(4.602 \pm 178)$ \\
\hline
\end{tabular}




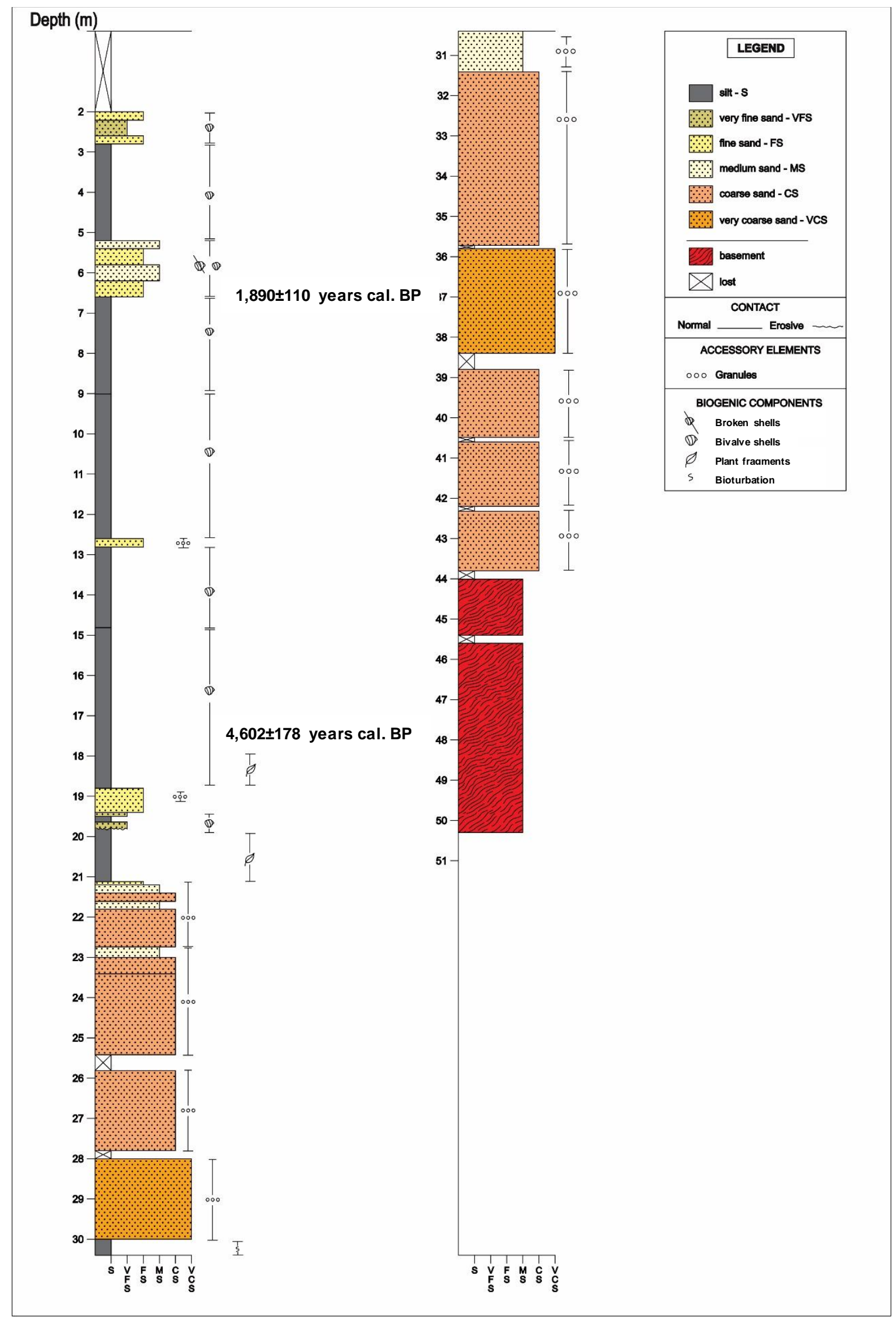

Fig. 4. Schematic representation of the grain size structure of SP2 core. This scheme shows granulometric reduction of sandy sediments upward between 43.80-21.15 m. Radiocarbon data are also included in this schematic representation. 


\subsection{Textural, Mineralogical and Foraminifera Occurrence}

The results of mean grain size (SMGS; $\mu \mathrm{m})$, the percentages of gravelly sand-fraction $(<63 \mu \mathrm{m} ; \%)$ and fine fraction $(<63 \mu \mathrm{m} ; \%)$, textural group classification, mineralogical composition of fine fraction, density of foraminifera and the geochemical results of the selected 17 sedimentary layers of the SP2 core are given in Appendix 1. The range of the analyzed variables values is presented in Table 3.

In the selected layers, sand-gravel $(>63 \mu \mathrm{m})$ and fine fractions $(<63 \mu \mathrm{m}$, including silt and clay fractions) content range from $2.3 \%$ to $20.9 \%$ (mean $=11.3 \pm 5.4 \%$; Table 3$)$ and $79.1 \%$ to $97.7 \%$ (mean $=88.5 \pm 5.3 \%$; Table 3 ). The sediment mean grain size (SMGS) oscillated between $44.3 \mu \mathrm{m}$ and 45.6 $\mu \mathrm{m}$ (mean $=44.8 \pm 0.3 \mu \mathrm{m})$.

Phyllosilicates are the main constituents of the sediments $(49.8-78.9 \%$, mean $=67.1 \pm 8.2 \%$;), followed by quartz $(9.7-$ $30.0 \%$, mean $=16.6 \pm 5.1 \%)$ and feldspars $(2.9-26.6 \%$, mean $=8.4 \pm 6.2 \%$ ), as shown in Table 3 . Pyrite and calcite are accessory minerals of the selected sedimentary layers. Siderite, opal C/CT, anatase, anhydrite and hematite were also identified in some layers. In addition, Illite $(68-74 \%<$, mean $=70 \pm 1.7 \%)$ and kaolinite $(26-32 \%<$, mean $=30 \pm 1.7 \%)$ were identified in the clay fraction of the selected layers (Appendix 2).

The depth plots in Fig. 5, show that the selected layers have small granulometric variability and small oscillation of phyllosilicates and calcite percentage. The sediments have low calcite contents $(0.4-3.1 \%$, mean $=1.9 \pm 0.8 \%$; Table 3). Pyrite is present in all selected layers $(0.5-6.7 \%$, mean $=3.5 \pm 1.7 \%$; Appendix 1).

In the analyzed core section, TOC and total sulfur (S) range between $1.0-2.7 \%$ (mean $=1.5 \pm 0.4 \%$; Table 3$)$ and 0.8 $1.7 \%$ (mean $=1.2 \pm 0.3 \%$; Table 3$)$, respectively (Fig. 6). The mean $\mathrm{C} / \mathrm{S}$ values are $1.3 \pm 0.6 \%$ (0.6-3.3\%; Table 3, Fig. 5). The abundance of foraminifera tests is quite variable $(<11,330$ $\mathrm{n}^{\circ} / \mathrm{g}$; mean $=2776 \pm 3336 \mathrm{n} / \mathrm{g}$; Appendix 1, Table 3). Foraminifera tests are present in most of the selected layers (Fig. 5).

The range of $\mathrm{Ag}, \mathrm{Al}, \mathrm{As}, \mathrm{Be}, \mathrm{Bi}, \mathrm{Ca}, \mathrm{Cd}, \mathrm{Co}, \mathrm{Cr}, \mathrm{Cu}, \mathrm{Fe}, \mathrm{K}$, La, Mg, Mn, Mo, Na, Nb, Ni, P, Pb, Sc, Sn, Sr, Th, Ti, V, Y, $\mathrm{Zn}$ and $\mathrm{Zr}$ concentrations, estimated for the core section between $3.6 \mathrm{~m}$ and $16.85 \mathrm{~m}$ are presented in Table 3. The depth plots for most of these chemical element concentrations are included in Appendix 3 and that of potentially toxic elements (PTE) concentrations and $\mathrm{P}$ are presented in Fig. 7.

The PTE concentrations ranged for the following elements: As - 12.0-22.0 mg/ $\mathrm{kg}$ (mean $16.6 \pm 2.6 \mathrm{mg} / \mathrm{kg}$ ); Cd - 0.4-0.6 mg/kg (mean 0.5 $\pm 0.1 \mathrm{mg} / \mathrm{kg}$ ); Co - 8.0-10.0 mg/kg (mean $8.9 \pm 0.8 \mathrm{mg} / \mathrm{kg}$ ); $\mathrm{Cr}-55.0-75.0 \mathrm{mg} / \mathrm{kg}$ (mean $68.0 \pm 4.8$ $\mathrm{mg} / \mathrm{kg}$ ); $\mathrm{Cu}-12.0-20.0 \mathrm{mg} / \mathrm{kg}$ (mean $14.4 \pm 1.8 \mathrm{mg} / \mathrm{kg}$ ); Ni $18.0-26.0 \mathrm{mg} / \mathrm{kg}$ (mean 23.4 $\pm 2.0 \mathrm{mg} / \mathrm{kg}$ ); $\mathrm{Pb}-22.0-26.0$ $\mathrm{mg} / \mathrm{kg}$ (mean $24.2 \pm 1.1 \mathrm{mg} / \mathrm{kg}$ ) and; $\mathrm{Zn}-70.0-92.0 \mathrm{mg} / \mathrm{kg}$ (mean $82.6 \pm 5.2 \%$ ). In the same layers the concentrations of $\mathrm{P}$ varied between $0.044-0.073 \%$ (mean $0.062 \pm 0.01 \%$ ).

Pearson correlations between geochemical data evidence that the PTE and P are significantly correlated with several lithogenic elements (Appendix 4). Principal Components Analysis (PCA) highlight (Fig. 7): the positive correlation of $\mathrm{Zr}$ and $\mathrm{K}$ (Group I) and the negative one of $\mathrm{As}, \mathrm{Cr}, \mathrm{Pb}, \mathrm{Zn}$, P, Nb, Al, Ti, Ni, Sn, V, Mg, Sc, Fe, Mo, Be (Group II) with the factor 1; the factor 2 of PCA is negatively correlated with $\mathrm{Cu}, \mathrm{Co}, \mathrm{Zn}, \mathrm{Fe}, \mathrm{Mo}, \mathrm{Be}, \mathrm{Ca}$, Th, La, Mn, Sr, Y (Group III). Both factors explain most part of data variability (Factor 1: 0.38\%; Factor 2: $0.25 \%$; total explained variability: $0.63 \%$ ).

Tab. 3. The range of values of the analyzed variables in this work. Legend: SD- standard deviation; SMGS - sediment mean grain size; Foram. D - foraminifera density; TOC - total organic carbon: S - total sulfur.

\begin{tabular}{|l|c|c|c|c|c|}
\hline Variables Range & & Maximum & Minimum & Mean & SD \\
\hline SMGS & $\mu \mathrm{m}$ & 45.6 & 44.3 & 44.8 & 0.3 \\
\hline Sand Fraction $(\mathbf{8 6 3} \boldsymbol{\mu m})$ & $\%$ & 20.9 & 2.3 & 11.3 & 5.4 \\
\hline Fine Fraction $(<\mathbf{6 3} \boldsymbol{\mu m})$ & $\%$ & 97.7 & 79.1 & 88.5 & 5.3 \\
\hline Phyllosilicates & $\%$ & 78.9 & 49.8 & 67.1 & 8.2 \\
\hline Opal C/CT & $\%$ & 3.3 & 0.0 & 0.4 & 0.9 \\
\hline Anatase & $\%$ & 3.1 & 0.0 & 0.7 & 0.9 \\
\hline Anhydrite & $\%$ & 1.5 & 0.0 & 0.5 & 0.6 \\
\hline Quartz & $\%$ & 30.0 & 9.7 & 16.6 & 5.1 \\
\hline Feldspars & $\%$ & 26.6 & 2.9 & 8.4 & 6.2 \\
\hline Calcite & $\%$ & 3.1 & 0.4 & 1.9 & 0.8 \\
\hline Hematite & $\%$ & 1.3 & 0.0 & 0.6 & 0.5 \\
\hline Siderite & $\%$ & 3.4 & 0.0 & 0.4 & 0.9 \\
\hline Pyrite & $\%$ & 6.7 & 0.5 & 3.5 & 1.7 \\
\hline
\end{tabular}


Tab. 3 (cont.). The range of values of the analyzed variables in this work. Legend: SD- standard deviation; SMGS - sediment mean grain size; Foram. D - foraminifera density; TOC - total organic carbon: S - total sulfur.

\begin{tabular}{|c|c|c|c|c|c|}
\hline \multicolumn{2}{|c|}{ Variables Range } & \multirow{2}{*}{$\begin{array}{c}\text { Maximum } \\
11330\end{array}$} & \multirow{2}{*}{$\begin{array}{c}\text { Minimum } \\
0\end{array}$} & \multirow{2}{*}{$\begin{array}{c}\text { Mean } \\
2776\end{array}$} & \multirow{2}{*}{$\begin{array}{c}\text { SD } \\
3336\end{array}$} \\
\hline Foram. D & n. $/ \mathrm{g}$ & & & & \\
\hline Foram. D & n. ${ }^{\circ} / \mathrm{g}$ & 11330 & 0 & 2776 & 3336 \\
\hline TOC & $\%$ & 2.7 & 1.0 & 1.5 & 0.4 \\
\hline $\mathbf{S}$ & $\%$ & 1.7 & 0.8 & 1.2 & 0.3 \\
\hline $\mathrm{C} / \mathrm{S}$ & $\ldots \ldots \ldots$ & 3.3 & 0.6 & 1.3 & 0.6 \\
\hline Ag & $\mathrm{mg} / \mathrm{kg}$ & 1.0 & $<0.5$ & 0.7 & 0.1 \\
\hline Al & $\%$ & 9.3 & 6.8 & 8.3 & 0.6 \\
\hline As & $\mathrm{mg} / \mathrm{kg}$ & 22.0 & 12.0 & 16.6 & 2.6 \\
\hline $\mathrm{Be}$ & $\mathrm{mg} / \mathrm{kg}$ & 3.0 & 2.0 & 2.4 & 0.5 \\
\hline $\mathbf{B i}$ & $\mathrm{mg} / \mathrm{kg}$ & $<5$ & $\ldots \ldots$ & $\ldots \ldots$ & $\ldots \ldots$ \\
\hline $\mathrm{Ca}$ & $\%$ & 1.5 & 0.3 & 1.0 & 0.4 \\
\hline $\mathrm{Cd}$ & $\mathrm{mg} / \mathrm{kg}$ & 0.6 & 0.4 & 0.5 & 0.1 \\
\hline Co & $\mathrm{mg} / \mathrm{kg}$ & 10.0 & 8.0 & 8.9 & 0.8 \\
\hline $\mathrm{Cr}$ & $\mathrm{mg} / \mathrm{kg}$ & 75.0 & 55.0 & 68.0 & 4.8 \\
\hline $\mathrm{Cu}$ & $\mathrm{mg} / \mathrm{kg}$ & 20.0 & 12.0 & 14.4 & 1.8 \\
\hline $\mathrm{Fe}$ & $\%$ & 5.6 & 4.1 & 4.9 & 0.3 \\
\hline $\mathbf{K}$ & $\%$ & 2.2 & 1.6 & 1.8 & 0.1 \\
\hline La & $\mathrm{mg} / \mathrm{kg}$ & 47.0 & 31.0 & 41.0 & 4.2 \\
\hline Mg & $\%$ & 1.5 & 1.0 & 1.4 & 0.1 \\
\hline Mn & $\mathrm{mg} / \mathrm{kg}$ & 545 & 326 & 433 & 61 \\
\hline Mo & $\mathrm{mg} / \mathrm{kg}$ & 9 & 2 & 3.8 & 1.6 \\
\hline $\mathrm{Na}$ & $\%$ & 1.2 & 0.91 & 1.1 & 0.1 \\
\hline $\mathrm{Nb}$ & $\mathrm{mg} / \mathrm{kg}$ & 22 & 18 & 19.2 & 1.0 \\
\hline $\mathbf{N i}$ & $\mathrm{mg} / \mathrm{kg}$ & 26 & 18 & 23.4 & 2.0 \\
\hline $\mathbf{P}$ & $\%$ & 0.073 & 0.044 & 0.062 & 0.008 \\
\hline $\mathrm{Pb}$ & $\mathrm{mg} / \mathrm{kg}$ & 26.0 & 22.0 & 24.2 & 1.1 \\
\hline Sc & $\mathrm{mg} / \mathrm{kg}$ & 13.0 & 9.0 & 11.8 & 1.0 \\
\hline Sn & $\mathrm{mg} / \mathrm{kg}$ & 4.0 & 3.0 & 3.7 & 0.5 \\
\hline Sr & $\mathrm{mg} / \mathrm{kg}$ & 151 & 84 & 122 & 21.4 \\
\hline Th & $\mathrm{mg} / \mathrm{kg}$ & 18.0 & 12.0 & 14.6 & 1.3 \\
\hline Ti & $\%$ & 0.6 & 0.5 & 0.5 & 0.0 \\
\hline $\mathbf{V}$ & $\mathrm{mg} / \mathrm{kg}$ & 97.0 & 69.0 & 87.4 & 6.4 \\
\hline $\mathbf{Y}$ & $\mathrm{mg} / \mathrm{kg}$ & 19.0 & 15.0 & 16.9 & 1.3 \\
\hline $\mathrm{Zn}$ & $\mathrm{mg} / \mathrm{kg}$ & 92.0 & 70.0 & 82.6 & 5.2 \\
\hline $\mathrm{Zr}$ & $\mathrm{mg} / \mathrm{kg}$ & 107 & 69 & 79.9 & 11.0 \\
\hline
\end{tabular}

\section{Discussion}

The sediment layers selected along the SP2 core were deposited between $\approx 1,730-2,345 \pm 178 \mathrm{BP}$ (estimated ages by interpolation, based on acquired radiocarbon data), during a period out of the high anthropic influence in the region (Lacerda et al., 1987). Most of the analyzed layers have abundant foraminifera tests (Appendix 1), which indicate that the study area was under the influence of marine waters for the most part of the studied period. Thus, the analyzed sediments could have been deposited in a marine transitional environment. 

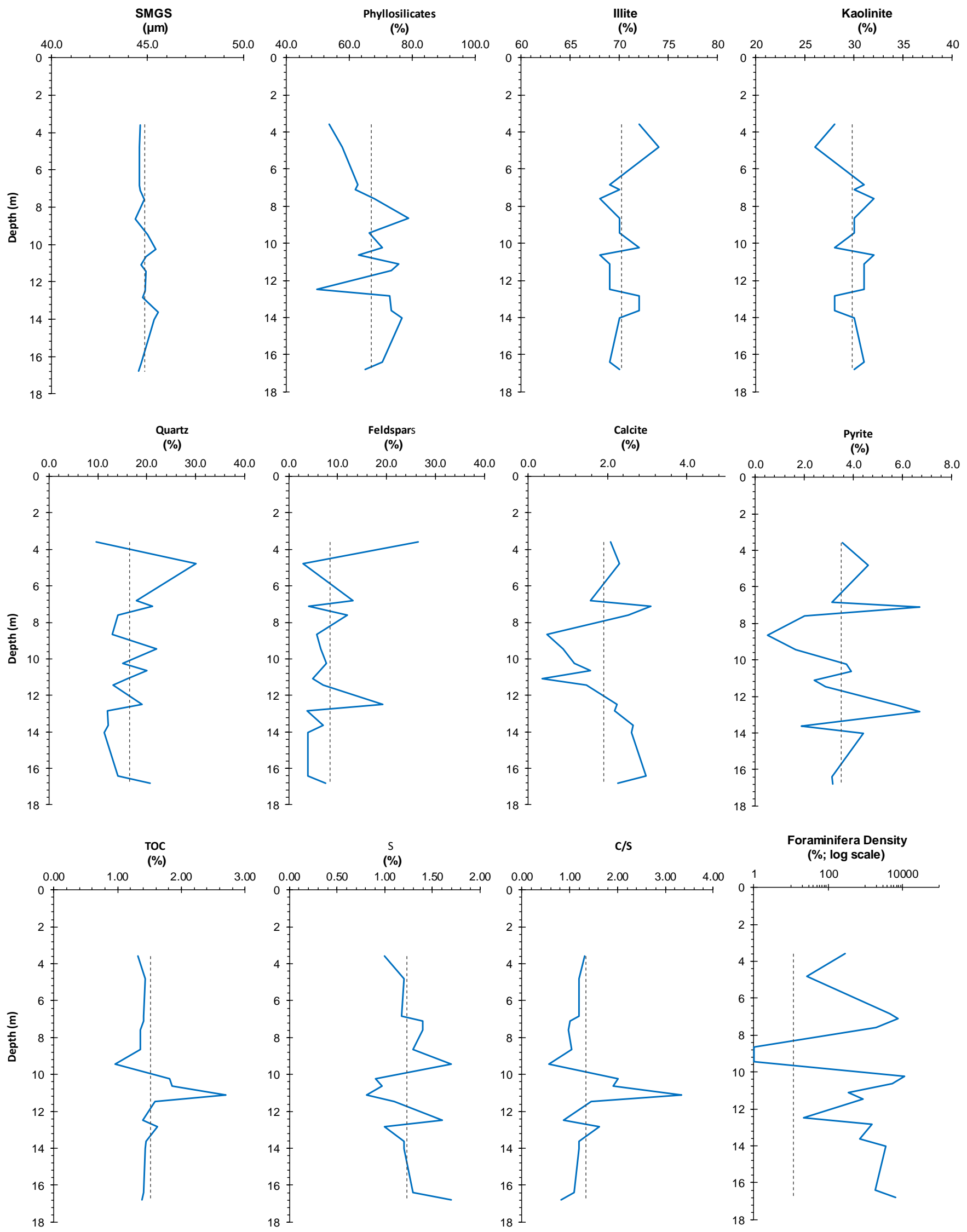

Fig. 5. Depth plots of sediment mean grain size (SMGS; $\mu \mathrm{m})$, phyllosilicates $(\%)$, namely illite and kaolinite $(\%)$, as well as quartz (\%), feldspars $(\%)$, calcite $(\%)$, pyrite $(\%)$. The depth plots of total organic carbon (TOC; \%), total sulfur (S; \%), C/S ratio values and foraminifera density $\left(\mathrm{n}^{\circ} / \mathrm{g}\right)$ are also presented. 


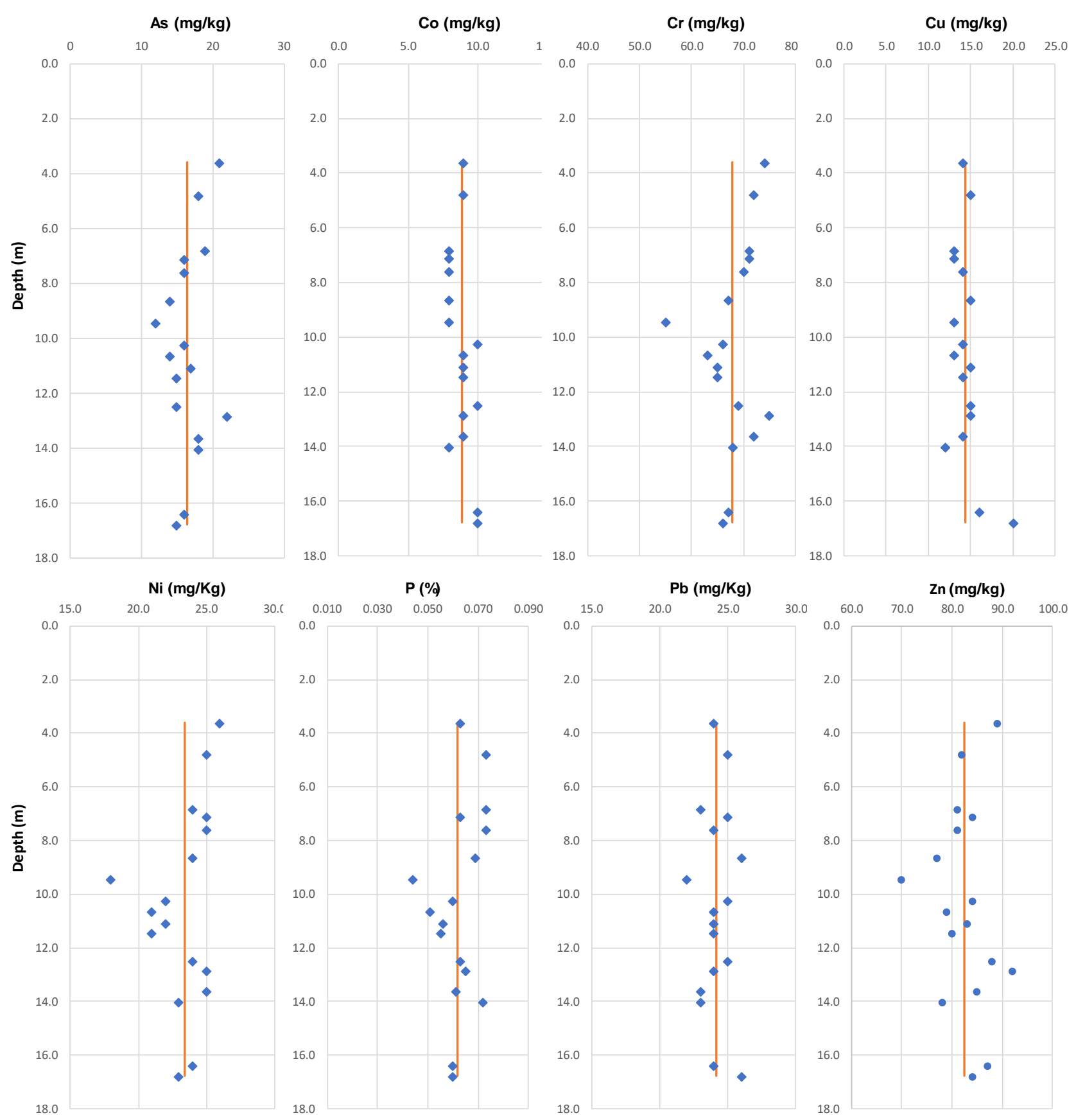

Fig. 6. Depth plots of potential toxic elements concentrations in the selected fine-grained layers of core SP2. The mean value for each chemical element is presented.

The sediment layers selected along the SP2 core were deposited between $\approx 1,730-2,345 \pm 178 \mathrm{BP}$ (estimated ages by interpolation, based on acquired radiocarbon data), during a period out of the high anthropic influence in the region (Lacerda et al., 1987). Most of the analyzed layers have abundant foraminifera tests (Appendix 1), which indicate that the study area was under the influence of marine waters for the most part of the studied period. Thus, the analyzed sediments could have been deposited in a marine transitional environment.

The analyzed sediments are fine-grained and siliciclastic with small granulometric variability and small calcite amounts (mean $1.9 \pm 0.8 \%$; Table 3). The lithology of the sediments source area to the studied site is complex (Valeriano et al., 2012), but the analyzed layers have poor mineralogical diversity, which indicates the presence of sediments that were submitted to several reworking and transport cycles and underwent significant mechanical and chemical weathering.

The selected layers are enriched in phyllosilicates, including illite $\left[\left(\mathrm{K}, \mathrm{H}_{3} \mathrm{O}\right)(\mathrm{Al}, \mathrm{Mg}, \mathrm{Fe})_{2}\left(\mathrm{Si}, \mathrm{Al}_{4}\right)_{4} \mathrm{O}_{10}\left[(\mathrm{OH})_{2},\left(\mathrm{H}_{2} \mathrm{O}\right)\right]\right.$ and kaolinite $\left[\left(\mathrm{Al}_{2} \mathrm{Si}_{2} \mathrm{O}_{5}(\mathrm{OH})_{4}\right]\right.$, which also coincides with the presence of calm hydrodynamic conditions during the 
deposition of these muddy layers (Ait-Mouheb et al., 2019).

Favorable rainy tropical climatic conditions, with dry winters and hot and rainy summers (SEMADS, 2001; Roncarati and Carelli, 2012), promote rich vegetation which is source of organic matter in the study area. Thus, relatively high TOC contents $(1.5 \pm 0.4 \%$; preserved organic matter) and relatively low $\mathrm{C} / \mathrm{S}$ values $(0.6-3.3 \% ; 1.3 \pm 0.6 \%)$ were recorded. $\mathrm{C} / \mathrm{S}$ values $<3$ in most of the layers indicate the potential development of suboxide conditions as a result of organic matter degradation (Duleba et al., 2018). Oxygen depletion and the establishment of anoxia in deeper sedimentary levels (Fan et al., 2018) favored the formation and preservation of pyrite.

It is common to find in fine-grained sediments, enriched in organic matter and having sulfide compounds, higher elemental concentrations than in coarse-grained sediments (Martins et al., 2015a, b). However, in the analyzed muddy layers of the SP2 core relatively, low PTE contents were found (Appendix 1; Table 4) when compared to the values recorded in polluted sediments of Sepetiba Bay, for instance, by Barcellos et al. (1991, 1992), Barcellos and Lacerda (1994) and Gomes et al. (2009).

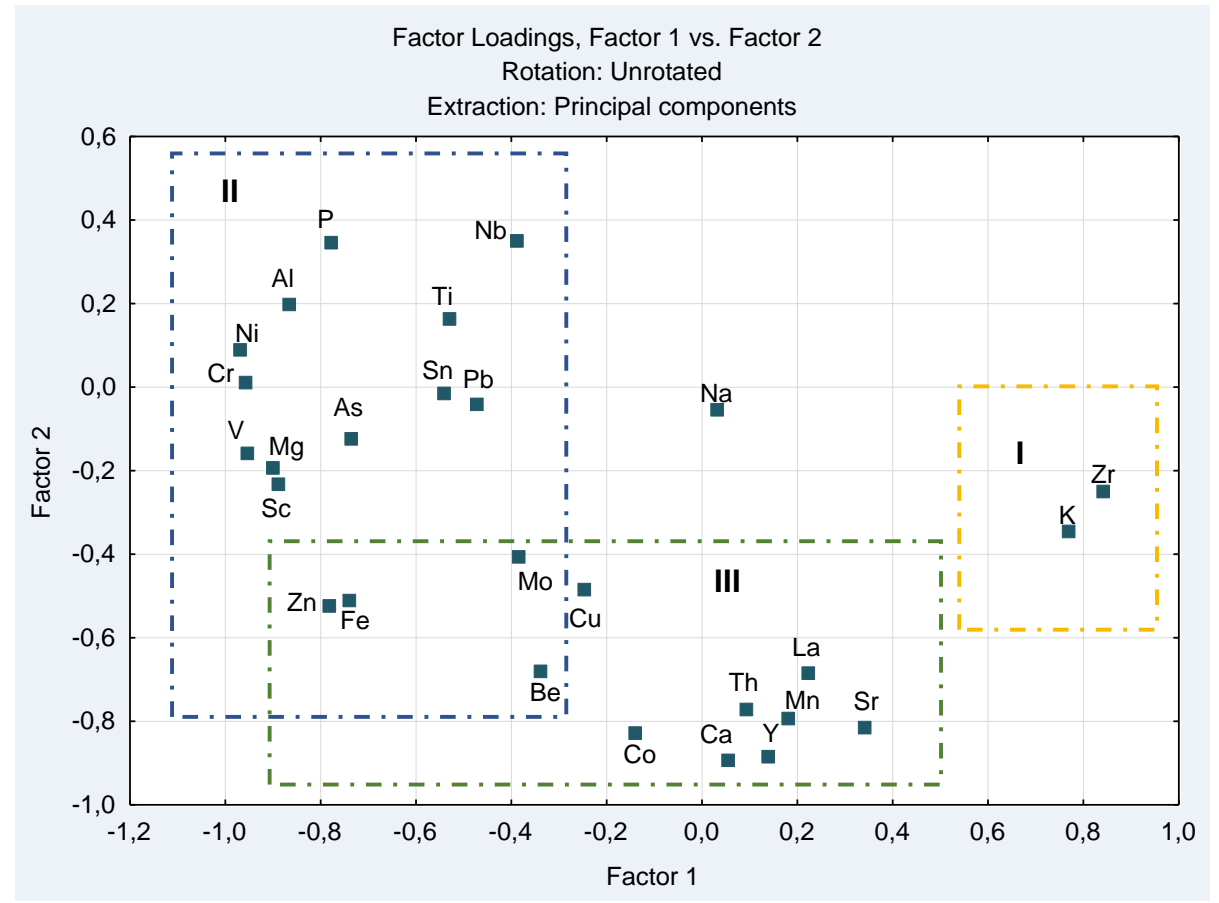

Fig. 7. Biplot of the factor 1 against the factor 2 of Principal Components Analysis based on chemical elemental concentrations.

The analyzed PTE concentrations are, in general, lower than the levels proposed by the Conselho Nacional do Meio Ambiente (National Council for the Environment CONAMA, resolution 344/2004) and Canadian Council of Ministers of the Environment (CCME, 1999) for the threshold effect level (TEL), and for the probable effect level (PEL), for marine sediments (Table 4). TEL is the concentration, at which, negative effects rarely occur in living beings, and PEL the concentration, at which, negative effects for living beings are expected to occur. These two levels of contamination were defined by Florida Department of Environmental Protection (FDEP, 1994), which published the "Development and Evaluation of Sediment Quality Assessment Guidelines" and later, by the Canadian Council of Ministers of the Environment (CCME 1999), published by the Canadian Sediment Quality Guidelines for the Protection of Aquatic Life", defining the "Interim Marine Sediment Quality Guidelines" (ISQG). The values of the ISQG are the same as those of TEL and PEL of FDEP (1994). In Brazil, the resolution CONAMA 344/2004 adopts the values proposed by Long et al. (1995) and recognizes two levels of contamination also mentioned in Table 4.

The correlations between the analyzed chemical elements (Appendix 4) and the PCA results (Fig. 7) suggest that the PTE concentrations are related to other lithogenic elements. For instance, $\mathrm{As}, \mathrm{Cr}, \mathrm{Ni}, \mathrm{Pb}, \mathrm{Zn}$, as well as $\mathrm{P}$, are positively correlated with Nb, Al, Ti, Sn, V, Mg, Sc, Fe, Mo, Be, whereas $\mathrm{Cu}, \mathrm{Co}$ and $\mathrm{Zn}$ are positively correlated with $\mathrm{Fe}, \mathrm{Mo}, \mathrm{Be}, \mathrm{Ca}$, Th, La, Mn, Sr, Y. The first group of chemical elements is common in the composition of the minerals present in igneous rocks. Th, La and $\mathrm{Y}$, for instance, are present in several minerals including monazite $\left[(\mathrm{Ce}, \mathrm{La}, \mathrm{Nd}, \mathrm{Th})\left(\mathrm{PO}_{4}\right.\right.$, $\left.\mathrm{SiO}_{4}\right)$ ], which is an accessory mineral of igneous and metamorphic rocks (e.g. granite, pegmatite, and gneiss; Spear and Pyle, 2002). Due to their resistance to weathering, these particles become concentrated in soils and sediments downslope from the source rock. Thus, the range of concentrations observed for the analyzed PTE (As, Cd, Co, $\mathrm{Cr}, \mathrm{Cu}, \mathrm{Ni}, \mathrm{Pb}, \mathrm{Zn}$ ) and $\mathrm{P}$, are related to natural sources of the sediments. 
The geological units present in the Guandu river basin may have influence on the composition of the studied sediments. So, the oldest rocks of Paleoproterozoic age observed in the region, are represented by gneisses of the Juiz de Fora unit (Duarte et al., 2000). These rocks are composed of tonalites, granodiorites and granites that represent sources of $\mathrm{Ca}, \mathrm{Na}$ and $\mathrm{K}$ by their calc-alkaline nature (with plagioclase, alkalinefeldspar, quartz, biotite and amphibole as major minerals).

In addition, in these rocks, $\mathrm{Zn}$ mineralizations have been reported which may result in increased concentrations of this element. The metasedimentary rocks that occur in this region, are probably Mesoproterozoic (Andrelândia Complex) or Neoproterozoic (São Fidelis) and are composed of gneisses with garnet, sillimanite and cordierite, besides feldspars and quartz.

The neoproterozoic rocks observed in the study area are composed of granite and syenite (quartz, felspars and biotite), possible sources of $\mathrm{Al}$ and $\mathrm{K}$. These rocks comprise the largest proportion in terms of area, which may increase their influence in the examined sediments.

Tab. 4. Range of concentrations of PTE and P in core SP2 in comparison with level 1 and 2 of CONAMA resolution 344/2004 and TEL and PEL of CCME (1999).

\begin{tabular}{lccccccccc}
\hline \multirow{1}{*}{ Variables } & $\mathbf{A s}$ & $\mathbf{C d}$ & $\mathbf{C o}$ & $\mathbf{C r}$ & $\mathbf{C u}$ & $\mathbf{N i}$ & $\mathbf{P}$ & $\mathbf{P b}$ & $\mathbf{Z n}$ \\
\cline { 2 - 9 } & $\mathbf{m g} / \mathbf{k g}$ & $\mathbf{m g} / \mathbf{k g}$ & $\mathbf{m g} / \mathbf{k g}$ & $\mathbf{m g} / \mathbf{k g}$ & $\mathbf{m g} / \mathbf{k g}$ & $\mathbf{m g} / \mathbf{k g}$ & $\%$ & $\mathbf{m g} / \mathbf{k g}$ & $\mathbf{m g} / \mathbf{k g}$ \\
\hline Maximum (SP2 core) & 22.0 & 0.6 & 10.0 & 75.0 & 20.0 & 26.0 & 0.073 & 26.0 & 92.0 \\
\hline Minimum (SP2 core) & 12.0 & 0.4 & 8.0 & 55.0 & 12.0 & 18.0 & 0.044 & 22.0 & 70.0 \\
\hline Mean (SP2 core) & 16.6 & 0.5 & 8.9 & 68.0 & 14.4 & 23.4 & 0.062 & 24.2 & 82.6 \\
\hline SD (SP2 core) & 2.6 & 0.1 & 0.8 & 4.8 & 1.8 & 2.0 & 0.01 & 1.1 & 5.2 \\
\hline Level 1 (CONAMA, 2004) & 8.2 & 1.2 & ---- & 81 & 34 & 20.9 & ---- & 46.7 & 150 \\
\hline Level 2 (CONAMA, 2004) & 70 & 9.6 & ---- & 370 & 270 & 51.6 & ---- & 218 & 410 \\
\hline TEL (CCME, 1999) & 7.24 & 0.7 & ---- & 52.3 & 18.7 & 15.9 & ---- & 30.2 & 124 \\
\hline PEL (CCME, 1999) & 41.6 & 4.2 & ---- & 160 & 180 & 42.8 & ---- & 112 & 271 \\
\hline
\end{tabular}

However, the maximum values recorded for: i) $\mathrm{Cu}$ and $\mathrm{Cr}$ exceed the TEL values (CCME, 1999; Table 4) but do not reach the minimum level of PEL (CCME, 1999; Table 4) and; ii) for As and $\mathrm{Ni}$ exceed the Level 1 of CONAMA (resolution 344/2004). These results indicate that a certain enrichment may occur for these trace elements by natural processes and due to the lithology of the source areas of the sediments carried by the drainage basins for the Sepetiba Bay lowland. However, this does not necessarily mean an increase in the availability of these metals in mobile phases of the sediments (Martins et al., 2015a).

Clay minerals have the property of absorbing and retaining certain ions in an exchangeable state (Carroll, 1959; Kahr and Madsen, 1995; Ma and Eggleton, 1999). The clay minerals found in the analyzed sediments, illite and kaolinite, should have not significant cation-exchange capacity, and probably do not favor a significant retention of metals by adsorption. Sometimes the coprecipitation of chemical elements with carbonates in marine sediment is significant (Förstner and Wittmann, 1981), but the proportion of carbonates is reduced and the biogenic carbonates are poorly preserved in the study area.

The processes of transport, deposition and remobilization of the sediments may have led to loss by leaching of chemical elements. It is possible that most of the determined elemental concentrations are associated to the crystallochemical composition of minerals.

\section{Conclusion}

The present study reports concentration ranges and mean values of PTE (As, Cd, Co, Cr, Cu, Ni, Pb, Zn) and P obtained in fine sediments in a transition zone of Sepetiba Bay (Rio de Janeiro, SE Brazil): As - 12.0-22.0 mg/kg (mean 16.6 \pm 2.6 $\mathrm{mg} / \mathrm{kg}$ ); Cd - 0.4-0.6 mg $/ \mathrm{kg}$ (mean $0.5 \pm 0.1 \mathrm{mg} / \mathrm{kg}$ ); Co - 8.0$10.0 \mathrm{mg} / \mathrm{kg}$ (mean $8.9 \pm 0.8 \mathrm{mg} / \mathrm{kg}$ ), $\mathrm{Cr}-55.0-75.0 \mathrm{mg} / \mathrm{kg}$

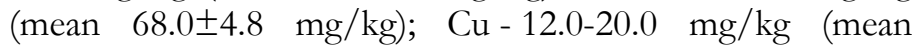
$14.4 \pm 1.8 \mathrm{mg} / \mathrm{kg}$ ); $\mathrm{Ni}-18.0-26.0 \mathrm{mg} / \mathrm{kg}$ (mean $23.4 \pm 2.0$ $\mathrm{mg} / \mathrm{kg}$ ); Pb - 22.0-26.0 mg/kg (mean 24.2 $\pm 1.1 \mathrm{mg} / \mathrm{kg}$ ); $\mathrm{Zn} \mathrm{-}$

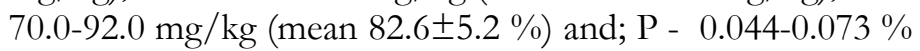
(mean $0.062 \pm 0.01 \%$ ).

Mean and concentration ranges of lithogenic chemical elements are also reported in fine sediments submitted to long transport and weathering processes in the region.

The results obtained in this study are of great interest in studies of reconstitution of anthropic influence and paleoenvironmental evolution of transitional environments of Rio de Janeiro State, but especially in Sepetiba Bay.

Appendices 1-4 are attached as supplementary materials (SM1-SM3) in https://www.e-publicacoes.uerj.br/index.php/jse/article/view/40992

\section{Acknowledgement}

This paper is a contribution of a project of Fundação Carlos Chagas Filho de Amparo à Pesquisa (FAPERJ) do Estado do Rio de Janeiro (FAPERJ; process \# APQ1 E26/111.398/2014) and of a project of 
the Conselho Nacional de Desenvolvimento Científico e Tecnológico (CnPQ, process \# 443662/2018-5). Virginia Martins would like to thanks the research grant provided by the $\mathrm{CNPq}$ (process \#301588/2016-3). This work was also financed by Fundação para a Ciência e a Tecnologia (FCT, Portugal) through the strategic project UID/GEO/04035/2013. The authors would like to thank the Fundação de Amparo à Pesquisa do Estado do Rio de Janeiro - FAPERJ by partial financial support of LGQM-UERJ and to Mr. Marcos Gonçalves of LGQM-UERJ and Gabriela Valdes of LGPA-UERJ for laboratorial technical support.

\section{References}

Ait-Mouheb, N., Schillings, J., Al-Muhammad, J., Bendoula, R., Tomas, S., Amielh, M., Anselmet, F., 2019. Impact of hydrodynamics on clay particle deposition and biofilm development in a labyrinth-channel dripper. Irrigation Science 37 (1), 1-10. https://doi.org/10.1007/s00271-018-0595-7

Almeida, F. F. M., Carneiro, C.D.R., 1998. Origem e evolução da Serra do Mar. Revista Brasileira de Geociências, São Paulo, 28 (2), 135-150.

Araújo, D.F., Peres, L.G.M., Yepez, S., Mulholland, D.S., Machado, W., Tonhá, M., Garnier, J., 2017. Assessing man-induced environmental changes in the Sepetiba Bay (Southeastern Brazil) with geochemical and satellite data. Comptes Rendus Geoscience 349, 290-298.

Barcellos, C., Lacerda, L.D., 1994. Cadmium and zinc source assessment in the Sepetiba Bay and Basin. Environmental Monitoring and Assessment, 29, 183-199. https://doi.org/10.1007/BF00546874

Barcellos, C., Lacerda, L.D., Rezende, C.E., Machado, J., 1992. Arsenic contamination in a coastal environment affected by a zinc smelting plant in Sepetiba Bay. In: Sancha, A.M.F. (Ed.) Proc Int Seminar Arsenic in the Environment its Incidence on Health. Universidad de Santiago, 25-29 May, Santiago, pp 5962

Barcellos, C., Rezende, C.E., Pfeiffer, W., 1991. Zn and Cd production and pollution in a Brazilian coastal region. Marine Pollution Bulletin 22, 558-561. https://doi.org/10.1016/0025326X(91)90896-Z

Blott, S.J., Pye, K., 2001. Gradistat: a grain size distribution and statistics package for the analysis of unconsolidated sediments. Earth Surface Processes and Landforms 26, 1237-1248. https://doi.org/10.1002/esp.261

Borges, H.V., Nittrouer, C.A., 2016a. Coastal sedimentation in a tropical barrier-island system during the past century in Sepetiba Bay, Brazil. Anuário do Instituto de Geociências - UFRJ, 39 (2), 5-14.

Borges, H.V., Nittrouer, C.A., 2016b. Sediment accumulation in Sepetiba Bay (Brazil) during the Holocene: A reflex of the human influence. Journal of Sedimentary Environments 1 (1), 96-112. https://doi.org/10.12957/jse.2016.21868

Brönnimann, P., Moura, J.A., Dias-Brito, D., 1981. Estudos Ecológicos na Baía de Sepetiba, Rio de Janeiro, Brasil: Foraminíferos. In: Anais do Congresso Latino-Americano de Paleontologia, Porto Alegre, RS, p. 862-875.

Cardoso, A.G.A., Boaventura, G.R., Silva-Filho, E.V., Brod, J.A., 2001. Metal distribution in sediments from the Ribeira Bay, Rio de Janeiro - Brazil. Journal of the Brazilian Chemical Society 6, 767-774. http://dx.doi.org/10.1590/S010350532001000600013
Carroll, D., 1959. Cation exchange in clays and other minerals. Bulletin of the Geological Society of America 70 (6), 749-780. http://dx.doi.org/10.1130/0016-7606(1959)70[749:ieicao]2.0.co,2

CCME, Canadian Council of Ministers of the Environment, 1999. Canadian Sediment Quality Guidelines for the Protection of Aquatic Life.

CONAMA, Conselho Nacional do Meio Ambiente, 2004. Resolução $\mathrm{N}^{\circ}$ 344, de 25 de março de 2004. Published in DOU $\mathrm{N}^{\mathrm{o}} 087$, of $07 / 05 / 2004$, pp. 56-57.

CPRM, Companhia de Pesquisa de Recursos Minerais, 2001. Projeto Rio de Janeiro. CPRM, Rio de Janeiro, Cd-Rom.

Desaules, A., 2012. Critical evaluation of soil contamination assessment methods for trace metals. Sci Total Environ 426, 120-131. http://dx.doi.org/10.1016/j.scitotenv.2012.03.035

Duarte, B.P., Heilbron, M., Neto, M.C.C., 2000. Granulite/charnockite from the Juiz de Fora Domain, central segment of the Brasiliano-Pan-African Ribeira belt. Revista Brasileira de Geociencias 30(3), 358-362. http://dx.doi.org/10.25249/0375-7536.2000303358362

Duleba, W., Teodoro, A.C., Debenay, J-P, Alves Martins M.V., Gubitoso, S., Pregnolato, L.A., Lerena, L.M., Prada, S. M., Bevilacqua, J. E., 2018. Environmental impact of the largest petroleum terminal in SE Brazil: A multiproxy analysis based on sediment geochemistry and living benthic foraminifera. PLoS ONE 13(2): e0191446. https://doi.org/10.1371/journal.pone.0191446

Dung, T.T.T., Cappuyns, V., Swennen Rudy, S., Phung, N.K., 2013. From geochemical background determination to pollution assessment of heavy metals in sediments and soils. Reviews in Environmental Science and Bio/Technology 12(4) 335-353. http://dx.doi.org/10.1007/s11157-013-9315-1

Espitalié, J., Laporte, L., Madec, M., Marquis, F., Leplate, P., Pault, J., Boutefeu, A., 1977. Methode rapid de caracterisation des rocks meres, deleur potential petrolier et leurdegre devolution. Oil \& Gas Science and Technology 32(1), 23-42. https://doi.org/10.2516/ogst:1977002

Fan, L.-F., Lin, S., Hsu, C.-W., Tseng, Y.-T. Yang, T.F., Huang, K.M., 2018. Formation and preservation of authigenic pyrite in the methane dominated environment. Deep Sea Research Part I: Oceanographic Research Papers 138, 60-71.

FDEP, 1994. Approach to the Assessment of Sediment Quality in Florida Coastal Waters. Vol. I. Development and Evaluation of Sediment Quality Assessment Guidelines. Prepared for Florida Department of Environmental Protection - FDEP, Office of Water Policy, Tallahasee, FL, by MacDonald Environmental Sciences Ltd., Ladysmith, British Columbia.

Folk, R.L., Ward, W.C., 1957. Brazos River bar: a study in the significance of grain size parameters. Journal of Sedimentary Petrology 27, 3-26. http://dx.doi.org/10.1306/74D706462B21-11D7-8648000102C1865D

Förstner, U., Wittmann, G.T.W., 1981. Metal Pollution in the Aquatic Environment, 486 S., 102 Abb., 94 Tab., BerlinHeidelberg-New York 1979. Springer-Verlag. DM 98.00 https://doi.org/10.1002/jobm.19810210712

Gałuszka, A., Migaszewski, Z.M., 2011. Geochemical back-ground - an environmental perspective. Minerologia 42(1), 7-17. https://doi.org/10.2478/v10002-011-0002-y

Gomes, F.C., Godoy, J.M., Godoy, M.L., Carvalho, Z.L., Lopes, R.T., Sanchez-Cabeza, J.A., Lacerda, L.D., Wasserman, J.C., 2009. Metal concentrations, fluxes, inventories and chronologies in sediments from Sepetiba and Ribeira Bays: A comparative 
study. Marine Pollution Bulletin 59, 123-133. https://doi.org/10.1016/j.marpolbul.2009.03.015

Heilbron, M., Pedrosa-Soares, A.C., Campos Neto, M., Silva L.C., Trouw, R.A.J., Janasi, V.C., 2004a. A Província Mantiqueira. In: Mantesso-Neto, V., Bartorelli, A., Carneiro, C.D.R., Brito Neves B.B. (eds.), O Desvendar de um Continente: A Moderna Geologia da América do Sul e o Legado da Obra de Fernando Flávio Marques de Almeida. São Paulo, Ed. Beca, cap. XIII, pp. 203-234.

Heilbron, M., Pedrosa-Soares, A.C., Campos Neto, M., Silva, L.C., Trouw, R. A J., Janasi, V.C., 2004b. Brasiliano Belts in SE Brazil. Journal of Virtual Explorer 17. www.virtualexplorer.au

Heilbron, M., Machado, N., 2003. Timing of terrene accretion in the Neoproterozoic-Eopaleozoic Ribeira orogen (SE Brazil). Precambrian Research 125, 87-112.

Herms, F., Gurgel, M. H., 2012. Distribuição espacial de metais pesados nos sedimentos da Baía de Sepetiba, RJ. In: Rodrigues, M.A.C., Pereira, S.D., Santos, S.B. (Org.), Baía de Sepetiba - Estado da Arte. 1ed, Rio de Janeiro: Corbã, p. 151-177.

Holland, H.D., Turekian, K.K. (Eds.), 2014. Treatise on Geochemistry. Elsevier, 2 ${ }^{\text {nd }}$ Edition, 9144 p.

Kahr, G., Madsen, F.T., 1995. Determination of the cation exchange capacity and the surface area of bentonite, illite and kaolinite by methylene blue adsorption. Applied Clay Science 9 (5), 327-336. https://doi.org/10.1016/0169-1317(94)00028-O

Kasilingam, K., Gandhi, M.S., Krishnakumar, S., Magesh, N.S. 2016. Trace element concentration in surface sediments of Palk Strait, southeast coast of Tamil Nadu, India. Marine Pollution Bulletin 111, 500-508. https://doi.org/10.1016/j.marpolbul.2016.06.051

Lacerda, L.D., Pfeiffer, W.C., Fiszman, M., 1987. Heavy metal distribution, availability and fate in Sepetiba Bay, S.E. Brazil. Science of The Total Environment 65, 163-173. https:/ / doi.org/10.1016/0048-9697(87)90169-0

Long, E.R., MacDonald, D.D., Smith, S.L., Calder, F.D., 1995. Incidence of adverse biological effects within ranges of chemical concentrations in marine and estuarine sediments. Environmental Management 19, 81-97. https://doi.org/10.1007/BF02472006

Ma, C., Eggleton, R.A., 1999. Cation exchange capacity of kaolinite. Clays and Clay Minerals 47 (2), 174-180.

Machado, N., Valladares, C., Heilbron, M., Valeriano, C., 1996. U$\mathrm{Pb}$ geochronology of the central Ribeira belt (Brazil) and implications for the evolution of the Brazilian Orogeny. Precambrian Research 69, 347-361. https://doi.org/10.1016/0301-9268(95)00103-4

Maia, R.M.C., Reis, A.T., Alves, E.C., Silva, C.G., Guerra, J.V., Gorini, C., Silva, A., Arantes-Oliveira, R., 2010. Architecture and Stratigraphic Framework of Shelf Sedimentary Systems Off Rio De Janeiro State, Northern Santos Basin-Brazil. Brazilian Journal of Oceanography, 58 (special issue, IGCP526), 15-29. https://doi.org/10.1590/S1679-87592010000500003

Marchand, C., Fernandez, J., Moreton, B., 2016. Trace metal geochemistry in mangrove sediments and their transfer to mangrove plants (New Caledonia). Science of Total Environment 562, 216-227. https://doi.org/10.1016/j.scitotenv.2016.03.206

Marques Jr., A.N., Monna, F., Silva-Filho, E.M., Fernex, F.E., Simões Filho, F.F.L., 2006. Apparent discrepancy in contamination history of a sub-tropical estuary evaluated through $210 \mathrm{~Pb}$ profile and chronostratigraphical markers. Marine Pollution Bulletin 52, 532-539. https://doi.org/10.1016/j.marpolbul.2005.09.048

Martins, V.A., Silva, F., Lazaro, L.M.L., Frontalini, F., Clemente, I.M., Miranda, P., Figueira, R., Sousa, S.H.M., Dias, J.M.A., 2015a. Response of benthic foraminifera to organic matter quantity and quality and bioavailable concentrations of metals in Aveiro Lagoon (Portugal). PLoS ONE 10 (2): e0118077. https://doi.org/10.1371/journal.pone.0118077

Martins, M.V.A., Mane, M.A., Frontalini, F., Santos, J.F., Silva, F.S., Terroso, D., Miranda, P., Figueira, R., Laut, L.L.M., Bernardes, C., Filho, J.G.M., Coccioni, R., Rocha, F., 2015b. Early diagenesis and adsorption by clay minerals important factors driving metal pollution in sediments. Environmental Science and Pollution Research, 22 (13), 10019-10033. https://doi.org/10.1007/s11356-015-4185-4

Martins, V., Dubert, J., Jouanneau, J. M., Weber, O., da Silva, E. F., Patinha, C. Rocha, F., 2007. A multiproxy approach of the Holocene evolution of shelf-slope circulation on the NW Iberian Continental Shelf. Marine Geology 239 (1-2), 1-18. http://doi.org/10.1016/j.margeo.2006.11.001

Matschullat, J., Ottenstein, R., Reimann, C., 2000. Geochemical background - can we calculate it? Environmental Geology 39 (9), 990-1000. http://doi.org/10.1007/s002549900084

Molisani, M.M., Marins, R.V., Machado, W., Paraquetti, H.H.M., Bidone, E.D., Lacerda, L.D., 2004. Environmental changes in Sepetiba Bay, SE Brazil. Regional Environment Change 4, 1727. http://doi.org/10.1007/s10113-003-0060-9

Muniz, P, Venturini, N., Gómez-Erache, M., 2004. Spatial distribution of chromium and lead in the benthic environment of coastal areas of the Río de la Plata estuary (Montevideo, Uruguai). Brazilian Journal of Biology 64 (1). http://dx.doi.org/10.1590/S1519-69842004000100012

Nesbitt, H.W., Young, G., 2008. Petrogenesis of sediments in the absence of chemical weathering: Effects of abrasion and sorting on bulk composition and mineralogy. Sedimentology 43(2), 341358. http://doi.org/10.1046/j.1365-3091.1996.d01-12.x

Pellegati, F., Figueiredo, A.M.G., Wasserman, J.C., 2001. Neutron activation analysis applied to the determination of heavy metals and other trace elements in sediments from Sepetiba Bay (RJ). Brazil. Geostandards and Geoanalytical Research 25(2-3), 307315. https://doi.org/10.1111/j.1751-908X.2001.tb00607.x

Ponçano, W.L., Fúlfaro, V.J., Gimenez, A.F., 1979. Sobre a Origem da Baía de Sepetiba e da Restinga da Marambaia - RJ. In: Simpósio Regional de Geologia, 2, Rio Claro, Anais v. 1, pp. 291304

Reimann, C., Garrett, R.G., 2005. Geochemical backgroundconcept and reality. Science of The Total Environment 350 (13), 12-27. https://doi.org/10.1016/j.scitotenv.2005.01.047

Reimer, P.J., Bard, E., Bayliss, A., Beck, J.W., Blackwell, P.G., Ramsey, C.R., Buck, C., Cheng, H., Edwards, R.L., Friedrich, M., Grootes, P.M., Guilderson, T.P., Haflidason, H., Hajdas, I. Hatté, C., Heaton, T.J., Hoffmann, D.L., Hogg, A.G., Hughen, K.A., Kaiser, K.F., Kromer, B., Manning, S.W., Niu, M., Reimer, R.W., Richards, D.A., Scott, E.M., Southon, J.R., Staff, R.A., Turney, C.S.M., Van Der Plicht, J. 2013. IntCal13 and Marine13 Radiocarbon Age Calibration Curves 050,000 Years cal BP. Radiocarbon, 55, 1869-1887. https://doi.org/10.2458/azu_js_rc.55.16947 
Roncarati, H., Barrocas, S.L.S., 1978. Estudo Geológico Preliminar dos Sedimentos Recentes Superficiais da Baía de Sepetiba. Relatório Interno CENPES/PETROBRAS, Rio de Janeiro, Brazil.

Roncarati, H., Carelli, S.G., 2012. Considerações sobre o estado da arte dos processos geológicos cenozóicos atuantes na Baía de Sepetiba. In: Rodrigues, M.A.C, Pereira, S.D, Santos, S.B. (Eds.). Baía de Sepetiba: Estado da Arte. Rio de Janeiro: Corbã, p. 13-36.

Schultz, L.G., 1964. Quantitative interpretation of mineralogical composition from X-ray and chemical data for the Pierre Shale. United States Geological Survey Professional Paper 391-C, 1-3.

Selley, R. C., 1970. Ancient sedimentary environments - and their sub surface diagnosis. Londres: Chapman \& Hall, 300 p.

SEMA (Secretaria de Estado do Meio Ambiente), ZEE-RJ (Programa De Zoneamento Economico-Ecologico Do Estado Do Rio De Janeiro-ZEE/RJ), 1996. Programa de zoneamento econômico-ecológico do estado do Rio de Janeiro Projeto 1: diagnótistico ambiental da bacia hidrágráfica da Baía de Sepetiba. Rio de Janeiro, Secretaria de Estado de Meio Ambiente, Universidade Federal do Rio de Janeiro, Empresa Brasileira de Pesquisa Agropecuária, Brazil.

SEMADS (Secretaria de Estado de Meio Ambiente e Desenvolvimento Sustentável), 2001. Manguezais: educar para proteger. Alves, J.R.P. (Org.), Rio de Janeiro: FEMAR: SEMADS, $96 \mathrm{p}$.

Silva L. C., McNaughton N.J, Armstrong R, Hartmann L.A., Fletcher I. 2005. The Neoproterozoic Mantiqueira Province and its African connections: a zircon-based U-Pb geochronologic subdivision for the Brasiliano/Pan-African systems of orogens. Precambrian Research, 136, 203-240. https://doi.org/10.1016/j.precamres.2004.10.004

Spear, F.S., Pyle, J.M., 2002. Apatite, Monazite, and Xenotime in Metamorphic Rocks. Reviews in Mineralogy and Geochemistry 48, 293-335. https://doi.org/10.2138/rmg.2002.48.7

Suguio, K., Vieira, E.M., Barcelos, J.H., Silva, M.S., 1979. Interpretação ecológica dos foraminíferos de sedimentos modernos da Baía de Sepetiba e adjacências, Rio de Janeiro. Revista Brasileira de Geociências 9 (4), 233-247.

Tack, F.M.G., Verloo, M.G., Vanmechelen, L., Van Ranst, E., 1997. Baseline concentration levels of trace elements as a function of clay and organic carbon contents in soils in Flanders (Belgium). The Science of the Total Environment 201, 113-123. https://doi.org/10.1016/S0048-9697(97)00096-X

Talma, A.S., Vogel, J.C. 1993. A simplified approach to calibrate C14 dates. Radiocarbon 35, 317-322.

Thorez, J., 1976.Pratical identification of clay mineral - A handbook for teachers and students in clay mineralogy. Belgium: Lelotte Editions, 91p.

Trouw, R.A.J., Peternel, R., Ribeiro, A., Heilbron, M., Vinagre, R., Duffles, P., Trouw, C.C., Fontainha, M., Kussama, H.H., 2013. A new interpretation for the interference zone between the southern Brasília belt and the central Ribeira belt, SE Brazil. Journal of South American Earth Sciences 48, 43-57. https://doi.org/10.1016/j.jsames.2013.07.01

Tupinambá, M., Teixeira, W., Heilbron, M., 2000. Neoproterozoic Western Gondwana assembly and subduction-related plutonism: the role of the Rio Negro Complex in the Ribeira Belt, South-eastern Brazil. Revista Brasileira Geociências 30, 7-11.

Valeriano, C.M. et al., 2012. Geologia e recursos minerais da folha Baía de Guanabara SF.23-Z- B-IV, Estado do Rio de Janeiro escala 1:100.000, Belo Horizonte: CPRM, 156 pp.

Villena, H.H., Pereira, S.D., Chaves, H. A. F., Dias, M.S., Guerra, J.V., 2012. Indícios da Variação do Nível do Mar na Baía de Sepetiba. In: Rodrigues, M.A.C., Pereira, S.D., Santos, S.B. (Eds.). Baía de Sepetiba: Estado da Arte. Rio de Janeiro: Corbã, p. 39-82.

Wasserman, J.C., Figueiredo, A.M.G., Pellegati, F., Silva-Filho, E.V., 2001. Elemental composition of sediment cores from a mangrove environment using neutron activation analysis. Journal of Geochemical Exploration 72, 129-146.

Wolanski, E., McLusky, D. (Eds), 2011. Treatise on Estuarine and Coastal Science. Academic Press, 4590 p. 